\title{
Evaluation of impact of daily Laurus nobilis tea consumption on the lipid profile and on the increased anti-oxidant activity in healthy volunteers
}

chahra chbili ( $\square$ chahrachbili@yahoo.fr)

Universite de Sousse https://orcid.org/0000-0002-5554-6882

Maoua Maher

Assiut University Faculty of Medicine

Mrad Sawssen

Assiut University Faculty of Medicine

Selmi Mejda

Assiut University Faculty of Medicine

\section{Boudriga Hajer}

Assiut University Faculty of Medicine

Khairi Hedi

Assiut University Faculty of Medicine

Limem Khalifa

Assiut University Faculty of Medicine

Mrizek Nejib

Assiut University Faculty of Medicine

Saguem Saad

Assiut University Faculty of Medicine

Ben Fredj Maha

Assiut University Faculty of Medicine

Research

Keywords: Biomarkers, HDL cholesterol, LDL cholesterol, Laurus nobilis, LDLR, SOD

Posted Date: May 28th, 2020

DOl: https://doi.org/10.21203/rs.3.rs-28846/v2

License: (1) (1) This work is licensed under a Creative Commons Attribution 4.0 International License.

Read Full License 
The authors have withdrawn this preprint from Research Square 